\title{
UNIVERSAL PARKING, INC.
}

\author{
Driving a hard bargain.
}

\section{BY JAMES ANDERSON}

A s a physics graduate student at a great technical university, my life was full. One of the things it was most full of was trying to find a parking space. I was not important enough to get a university sticker and not rich enough to afford a pay lot.

One day, I had even less luck finding a space than usual. As I walked the many blocks back to my lab, I passed a new store front with an enticing sign in the window: "Universal Parking, Inc. - Affordable Parking".

Sitting behind the counter was my old buddy, Alfred, who had left our graduate programme the previous year after a noisy altercation with his adviser.

I stuck my head through the door. "What's happening, Al?" I asked.

"I joined the private sector," he replied. "This is my new start-up."

"How can you provide cheap parking so near the university?"

"You'd be surprised," he said with a grin. "Our lab studies quantum computers, right? And quantum computers need error correction to get reliable results. So I wanted to see if the errors had structure.

"Guess what, they did. Decoded, the errors formed a message - in fact, they formed an advertisement. In English. It said: 'Need money? Make big bucks solving the perennial urban problem: parking. Buy a parking franchise from Universal Parking, Inc. Not sold in stores.' It gave instructions on how to build a device to contact the advertiser. So, of course, I told my adviser. And, naturally, he thought I was nuts and kicked me out." He sighed.

"With my graduate career ended, I had no income. So I did the only thing I could do: I put together the contact device using a 1950s short-wave radio and a vacuum-tube stereo amplifier. Apparently, vacuum tubes are critical. And here we are," he waved his hands.

"Their parking technology is based on the many-worlds model of quantum mechanics. You park your car in an alternative universe. They provide the hardware and software to park the cars and get them back. You drive the car onto the transmitting pad, press a button and the car goes away. Press another button and it comes back."

I was speechless. Al

$\rightarrow$ NATURE.COM

Follow Futures:

@ @NatureFutures

f go.nature.com/mtoodm had been in business for only a month and was already making money hand over fist.
He'd even visited the parking lot. In a parallel universe. How could I resist?

"Any chance you'd take an old lab mate to see this lot?" I asked. After all, the scheme had to be using some radical new physics.

"Why not?" Al shrugged, and gestured at the nearest car. We clambered in and he

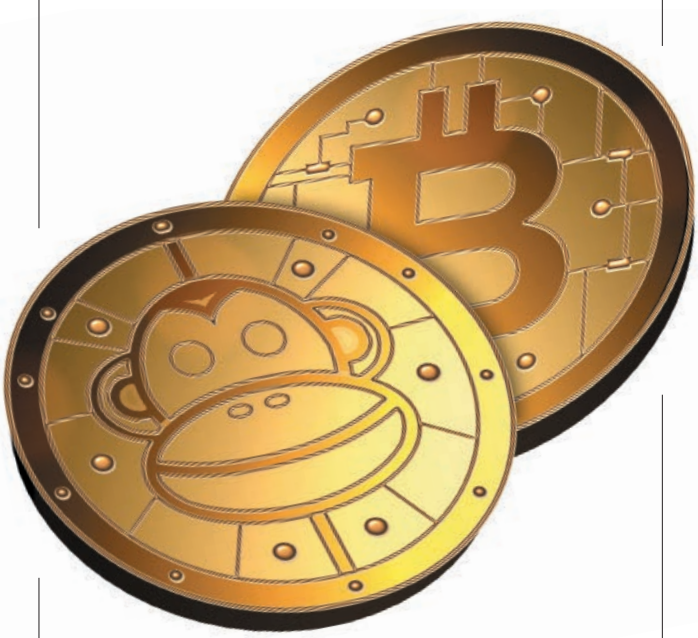

pressed a button on his remote. Immediately, we found ourselves in the middle of a vast flat area. The lot stretched away in every direction, neatly marked into spaces. Every few yards stood a sign with a cartoon drawing of an ape.

A huge number of cars were already parked. Their shapes were similar to those at home but they had unfamiliar names. We saw a sporty Chrisler Baalrog and a pink, jacked up pick-up with massive wheels, a GMD Epicene. There was a Fórd Pantocrator sedan and a Fárd Oriflamme coupé. Two of the most striking vehicles were a sedan with three headlights, the Archimandrite Trinitarian, and a four-axle, eight-wheeled VWW Octopus.

Occasionally, with a pop, a new car appeared. Sometimes a car vanished with a loud sucking noise.

A faint rasping noise reached our ears. In the distance, we could make out an entity riding towards us in what looked like a melted golf cart. As it got closer, we could see that the creature was tall, thin, approximately human, and dressed in a glowing cerise uniform.

He pulled up next to us. A box at his belt spoke in oddly accented English. "Welcome to our endeavour. I am joyful you found us. As new worlds join Universal Parking, we dedicate to them a portion of our parking facilities. We recently opened a section for primitive primates such as yourselves. I am the parking attendant. I have arrived to collect our fee."

He read our itemized bill. "One, initial franchise fee. Two, cost per car storage. Three, cost per car retrieval. Four, fee for getting lost in the parking lot. Five, fee for getting found. Six, fee for talking to parking-lot staff."

He removed a page from a notebook and handed it to Al. "We expect your payment in bitcoins by next week. The modest amount you owe is roughly equivalent to the income of one of your local administrative units such as a state.

"If you can't find enough bitcoins I suggest arranging for the indentured servitude of a few hundred of your best hackers. We always need to upgrade our software and expand our operations and possibly cause our competitors operational difficulties.

"We expect prompt payment. Otherwise we will engage our collection agent whom I suspect you will find it difficult to like."

He was about to leave when a second entity appeared, seemingly out of nowhere. This one was short, pudgy and vivid orange, including his jumpsuit, eyes and skin.

He glared at the attendant. "Stop bothering these primitives. We have warned you before. Next time, we will impose financial encumbrances with appropriate chastisement. Go back to your educational cluster. Return no more."

The parking attendant and cart vanished with a sucking sound.

The newcomer turned to us. "Be thankful we saved you from a low-quality fraudster," he said. "He could have bankrupted your obscure planet. You were taken in by the 'Parking via quantum mechanics' scam. This scam works only with entities at or below the level of business acumen of the primitives from your planet who traded prime Manhattan real estate for a handful of transistors. This is not even his parking lot; it belongs to the Omniverse Shopping Mall.

"We will send you and your cars home, and sever your first-order connection with the multiverse. Get in contact with us when you figure out what bitcoin mining really does."

He vanished.

$\mathrm{Al}$ and I waited to be transferred home, having learnt to be careful of new physics.

James Anderson first subscribed to Astounding Science Fiction at the age of 12. His day job is professor of cognitive science at Brown University, where he constructs neural network models for cognition. 